\title{
中学生におけるクラスの動機づけ構造の認知に関する探索的検討
}

\author{
谷島 弘 仁 ${ }^{1}$ 新 井 邦二郎 2
}

\section{AN EXPLORATION OF MOTIVATIONAL STRUCTURE IN A CLASSROOM OF JUNIOR HIGH SCHOOL STUDENTS}

\author{
Hirohito YaJima AND Kunijiro ARAI
}

\begin{abstract}
The purpose of this study was to explore the construction of the motivational structure in the classroom and to investigate how this structure would be related to junior high school students' relevant elements in actual classroom settings. Three -hundred and fifty seventh graders were given questionnaires on their perceptions of the motivational structure in the classroom, containing some relevant elements in students, (i.e., their perceived abilities, self-esteem, and causal attributions), and some relevant elements in the classroom, (i.e., students' perceived classroom culture, classroom aptitude, and students' morale). The motivational structure in the classroom was evaluated using a recognition scale, a task orientation scale, a participation scale, and a cooperation scale. This investigation showed the following results. The factor analysis revealed four factors of the motivational structure in the classroom as perceived by students. Each scale of the motivational structure in the classroom was correlated with relevant elements in students. Also, each scale in the classroom motivational structure explained each element in the classroom, particularly, perceived classroom culture, their classroom aptitude, and some sub-elements of classroom morale.
\end{abstract}

Key words : the motivational structure in the classroom, recognition, task orientation, participation, cooperation.

\section{問題の所在}

学校教育における動機づけは，これまで主に個人の 内的要因が問題とされてきた。そのなかで, 内発的動 機づけやコンピテンスの概念 (Brophy, 1983) と並んで, 最近では達成目標の認知などが児童・生徒個人の動機 づけの要因としてとりあげられ，研究されてきている (Ames \& Archer, 1988 ; Nicholls, Patashnick, \& Nolen, 1985 ; 渡辺, 1990)。しかし，これらの個人内要因としての動

1 筑波大学大学院 (Doctoral Program in Psychology, University of Tsukuba)

2 筑波大学心理学系 (Institute of Psychology, University of Tsukuba)
機づけが必ずしもクラスの様々な活動場面や教科の授 業場面での指導に効果的に利用されてきたとは言えな い面があるものと思われる。クラスは教師と多数の児 童・生徒から構成されている複雑な相互作用の場であ り，さらに授業は，その特質が様々に異なる教科に関 連して行われるため, 教師は内発的動機づけやコンピ テンスの概念を授業のどのような場面で，どのような 子どもに適用し指導に活用すればよいのかについて， 必ずしもよい知見を得られなかった面があるのではな いだろうか。すなわち，これらの動機づけの概念は， 個人の動機づけを明らかにするうえでは貢献したが, クラスの場面では必ずしも有効ではなかったと思われ る。 
速水 (1993) は，クラスにおける外発的動機づけと内 発的動機づけが連続帯状にあり, 生徒の内発的動機づ けに対して外発的動機づけが重要な役割を持つことを 指摘し，外発的動機づけと内発的動機づけのリンク信 条理論を提唱している。また, Stipek (1993) は, 一定 のクラスの条件のもとで外発的動機づけが内発的動機 づけに大きな意味を持つことを述べている。それゆえ， 動機づけの外発的側面と内発的側面を包含した，クラ ス全体の指導に効果を持つ動機づけの概念の構築が新 たに必要とされていると言えよう。その際，クラスに おける動機づけの役割は大きなものであることが予想 される。

クラスに関連した研究として, 我国においては, ク ラスの環境や心理的雾囲気については, 従来より社会 心理学の分野で研究されてきている（例えば, 田崎・狩野, 1990)。これらの領域においては, 教師一生徒関係につ いても多くの知見が得られている（浜名, 1988）。また， 主として教育社会心理学の立場からクラス構造に関す る尺度を作成した根本（1983）の先駆的な研究がある。 しかし，クラスにおける動機づけに焦点をあてた研究 は, 渡辺 (1990) などを除いて, 多くはなされていない のが現状である。

Ames(1987)は, これまでの環境としてのクラスに関 する研究について, クラス環境を構成する下位次元の 設定が非常に曖昧であり，とりわけ動機づけの次元か ら教師が効果的な介入方略を採用するための知見が示 されていないことを問題点として指摘している。また， このような問題を克服するためにクラスの動機づけの 次元に関する理論的な枠組みを構築することが不可欠 であることを述べている。

最近では, Ames(1987)が指摘するように, 主として 動機づけの観点からクラス構造をとらえ直し, 得られ た知見を教育実践に適用していこうとする研究の流れ がある（例えば, Meece, Blumenfeld, \& Puro, 1989)。このよ うに, クラス単位での動機づけを問題とする研究にお いては, クラスにおける動機づけの下位構造を設定し, その下位構造に基づいて動機づけ方略を採用し, 生徒 を動機づけていくという考え方が提案されている（Epstein, 1988)。すなわち, クラスを動機づけの次元にした がって構造化し，その各々について教授方略を提案し， その効果を分析していく, 理論的研究と授業実践を結 びつける方法がとられている (Maehr \& Midgley, 1991)。

この点に関して, Epstein(1988) は, クラス構造を以 下の 6 つの側面に分類し, これらの頭文字を取って TARGET 構造と名づけた。すなわち, 課題(task), 権
限 (authority), 報酬 (reward), グルーピング (grouping), 評価 (evaluation), 時間 (time) の各次元から構成 される。このような構造化の基本的な前提は，クラス は操作可能な構造を成しているというものである。

Epstein によれば,クラスにおける操作可能な構造 が生徒の学業場面での行動や非学業場面での行動に及 ぼす効果に関する研究は，アメリカにおける中等課程 の公教育において, 人種や社会・経済的出身など背景 が複雑に異なる生徒の多様性に対応することを目的と しているという。Maehr \& Midgley(1991)は, Epstein による TARGET 構造の各側面に関する理論を詳細 に検討し，各側面の焦点と目標，それらを実施する上 での方略を分類した。とりわけ，報酬（reward）構造に ついて, 生徒を承認する機能の方が優勢であるとし, 承認構造 (recognition) として, 再定義している (TABLE 1参照)。また, Ames (1992) が, Epstein (1988) による TARGET 構造を検討し, 主として達成目標との関連 からクラスを課題志向的にするために有効なクラス構 造を課題構造, 評価・承認構造, 権限構造の 3 つの成 分に分類している。

このように, クラスの動機づけの構造化に関する概 念は, 教師がクラスで効果的に指導するための次元と して設定されているが，これらの枠組みを日本におけ るクラス場面に対し導入するためには，いくつかの問 題点が指摘できる。第 1 に, 先行研究において設定さ れたクラスの動機づけの次元は, 主として理論面のみ から導かれており, 子どもに対してのクラスの動機づ け構造に関する実証的な研究は, 現在のところなされ ていない。それゆえ, 子どもは実際にはクラスの動機 づけ構造として，どのような次元を認知しているのか， 言いかえれば，学習を中心とする様々な活動へ子ども を動機づける環境とはどのようなものであるのかを， 子ども自身の認知を通して明らかにしていくことが必 要である。子どもが認知したクラスの動機づけ構造の 次元が理論的枠組みと合致するなら,これらの枠組み に基づく教師の動機づけ方略の設定や, 動機づけの次 元における生徒への介入は, 教育実践においてより有 効なものとなろう。第 2 に, 従来から, アメリカにお ける人間関係は競争的であり, 日本の人間関係は親和 的であるという指摘がなされてきたが（例えば, 長谷川, 1991), 同様にアメリカのクラス環境と日本のクラス環 境について大きな文化的差異の存在が予想されるため (喜多村, 1992 ; 塩見, 1994), 日本においてあてはまるク ラスの動機づけ構造の下位次元についての検討が必要 とされる。例を挙げれば, Epstein(1988)は, TARGET 
TABLE 1 TARGET 構造の内容と方略 (Maehr \& Midgley, 1991 より作成)

\begin{tabular}{|c|c|c|c|}
\hline TARGET 領域 & 焦 & 目 & 略 \\
\hline $\begin{array}{l}\text { Task } \\
\text { (課題) }\end{array}$ & 学習の内発的価値 & $\begin{array}{l}\text { 外的誘因への依存の減少 } \\
\text { すべての生徒に挑戦させるプロ } \\
\text { グラムの設計 } \\
\text { 学習における目標や, 目的を強 } \\
\text { 調するプログラムの促進 } \\
\text { 学習の楽しさの強調 }\end{array}$ & $\begin{array}{l}\text { 生徒の背景と経験の利点を役立たせるプログラム } \\
\text { の推奨 } \\
\text { 参加・成績・達成などに対する報酬を避ける } \\
\text { 目標設定や自己制御管理を強調 } \\
\text { 様々な非学校場面(例えば, 実習, 実体験, ボラン } \\
\text { ティア活動)において学校学習を利用するプロ } \\
\text { グラムの推進 }\end{array}$ \\
\hline $\begin{array}{l}\text { Authority } \\
\text { (権限) }\end{array}$ & $\begin{array}{l}\text { 学習の決定事項や, 学校の決定 } \\
\text { 事項への生徒の参加 }\end{array}$ & $\begin{array}{l}\text { 責任や自立, 指導技術を開発す } \\
\text { る機会の提供 } \\
\text { 自己制御スキルの発展 }\end{array}$ & $\begin{array}{l}\text { 教授場面における最適な選択の提供 } \\
\text { ボランティア活動場面や課外活動場面への参加の } \\
\quad \text { 促進 } \\
\text { 自己制御へのメ夕認知方略を学習する機会の推進 }\end{array}$ \\
\hline $\begin{array}{l}\text { Recognition } \\
\text { (承認) } \\
\text { (Epstein によれ } \\
\text { ばreward構造) }\end{array}$ & $\begin{array}{l}\text { 学校場面における承認および報 } \\
\text { 酬の性質と使用 }\end{array}$ & $\begin{array}{l}\text { すべての生徒が承認される機会 } \\
\text { の提供 } \\
\text { 目標達成の進歩の承認 } \\
\text { 学習活動についての広い配列に } \\
\text { おける努力の承認 }\end{array}$ & $\begin{array}{l}\text { 「自分なりにベストをつくす」ことへの承認の促進 } \\
\text { 全生徒と, 彼らの達成が認知され得る指導の推進 } \\
\text { 生徒のはば広い学校関連活動の公認と公表 }\end{array}$ \\
\hline $\begin{array}{l}\text { Grouping } \\
\left(\begin{array}{l}\text { (グルーピング) }\end{array}\right.\end{array}$ & $\begin{array}{l}\text { 生徒の相互作用, 社会的スキル, } \\
\text { 価値 }\end{array}$ & $\begin{array}{l}\text { 全生徒を受容し評価する環境の } \\
\text { 建設 } \\
\text { 特に非行などの危険のある生徒 } \\
\text { の社会的相互作用の範囲拡大 } \\
\text { 社会的スキルの発達を高める } \\
\text { みんなが, 自分を重要な貢献を } \\
\text { する能力があるとみなし得る } \\
\text { 環境を建設する }\end{array}$ & $\begin{array}{l}\text { ブループによる学習・問題解決・意志決定の機会 } \\
\text { の提供 } \\
\text { 仲間との相互作用が生じ時間と機会を認める } \\
\text { 重要な相互作用が生じ得る下位グループ(チーム } \\
\text { や学校内学校など)の発達を促進する } \\
\text { 仲間の相互作用の範囲を増加させるための多次元 } \\
\text { グループ㷌属の推奨 }\end{array}$ \\
\hline $\begin{array}{l}\text { Evaluation } \\
\text { (評価) }\end{array}$ & 評価と評価手続の性質と使用 & $\begin{array}{l}\text { 生徒の有能感と自己効力感を増 } \\
\text { 加させる } \\
\text { 技術と理解の発展の進歩につい } \\
\text { ての生徒の知覚を増加させる } \\
\text { 生徒の独自な才能の自賞を増加 } \\
\text { させる } \\
\text { 学習と生活の一部としての失敗 } \\
\text { の受容を増加させる }\end{array}$ & $\begin{array}{l}\text { 集団準拠評価(成績やテストの点数)への公的準拠 } \\
\text { を最少にすることで, 達成の社会的比較への強 } \\
\text { 調を滅少させる } \\
\text { 生徒たちに自分の遂行を改善させる機会を与える } \\
\text { 政策と手続を確立する } \\
\text { 生徒たちに, 自分たちの設定する目標への進歩を } \\
\text { 評価させる機会をつくる }\end{array}$ \\
\hline $\begin{array}{l}\text { Time } \\
\text { (時間) }\end{array}$ & $\begin{array}{l}\text { 計画と到達目標を実行する時間 } \\
\text { の運営 }\end{array}$ & $\begin{array}{l}\text { 作業完成率の改善 } \\
\text { 計画や実行の技術の改善 } \\
\text { 自己管理能力の向上 } \\
\text { 学習課題や, 生徒の必要性を時 } \\
\quad \text { 間割りに反映させる }\end{array}$ & $\begin{array}{l}\text { 目標とする成績をとる計画を実行するうえで, 個 } \\
\text { 人目標の設定や, 進歩のモニターの経験を提供 } \\
\text { する } \\
\text { 時間管理技術を発達させる機会を促進 } \\
\text { 可能な限り, 生徒自身の速度での進歩を認める } \\
\text { 学習経験に関する時間割りの柔軟性を推奨する }\end{array}$ \\
\hline
\end{tabular}

構造の下位次元として時間の次元を設定しているが, この次元は，米国の中等教育における公立学校に焦点
をあてたものであり，様々な民族が混在し，統一的な 学習指導要領が存在せず, オープンエデュケーション 
に代表されるように教師が比較的自由に時間割を設定 することができる米国の教育事情と (喜多村, 1992)，統 一された学習指導要領が存在し, ほとんどの授業が決 められた時間割に従い一斉授業で進められる我国の教 育事情の間には大きな差異が存在することが予想され， Epstein らによる次元がそのまま日本のクラス場面に 適用できるとは限らないものと思われる。新たに日本 の教育場面に適用可能な理論的枠組みを構築すること で, 下位次元に基づく効果的な動機づけ方略を採用す る手がかりの得られることが期待される。

以上のような問題点に対し本研究では, Epstein (1988)による TARGET 構造の次元を参考にして, ク ラスの動機づけ構造を, 教師がクラスにおいて生徒を 効果的に動機づける上での, 授業およびクラス運営上 の実践的枠組みとして定義し, 中学生を対象に, 日本 のクラスにあてはまるクラスの動機づけ構造の次元を 新たに構成することを第 1 の目的とする。つぎに, 構 成されたクラスの動機づけの次元と, 関連する個人の 様々な特性およびクラスにおける諸要因との関係を探 索的に検討することを第 2 の目的とする。

\section{方法}

調査対象 本研究は, クラスの動機づけ構造を問題 にしているが，小学校においては一人の学級担任がほ ほすべての教科を担当することもあり，クラスの動機 づけ構造に与える教師の要因が大きすぎると考えたた め, 調査対象を中学校に限定した。また, 中学校 3 年 生のように受験が近い状態では, 受験の要因が大きく 影響すると考えられるため, これらの要因が比較的小 さいと思われる中学校 1 年生を調查対象とした。

調査には，地域の異なる 2 校 ( $\mathrm{A}$ 校および $\mathrm{B}$ 校) の中学 校 1 年生が参加した。A校は 5 クラスが参加し, 男子 67名, 女子 83 名の合計 150 名が調査対象となった。B校 は 6 クラスが参加し, 男子108名, 女子 92 名の合計 200 名が調査対象となった。すなわち，総計11クラス, 350 名が調查に参加した。また， 2 週間後の再検査信頼性 の測定には, B校のうちの 2 クラス, 53 名が参加した。 しかし, 被験者全員がすべての測度項目に漏れなく回 答しているわけではないため, 測度項目によって被験 者数が異なるものもある。

調查時期 1994年 2 月下旬 3 月初旬

\section{調查内容}

(1)クラスの動機づけ構造を測定する質問項目

Epstein (1988) および Maehr \& Midgley (1991) の 次元を参考にして日本のクラスにあてはまる次元とし
て課題志向, 権威, 承認, 協調, 参加を仮定した。こ れらの要因の決定は, 以下のように行った。茨城県内 の 3 名の教師（1 名は男性で, 国語科専攻。教師経験は 18 年。 2 名は女性で, ひとりは数学科専攻であり, 教師経験は 17 年。もう ひとりは理科専攻であり，教師経験は 15 年であった）に対し， Epstein（1988）およびMaehr \& Midgley（1991）によ るクラスの TARGET 構造の各次元を説明し，これを 参考にして新たに日本のクラス場面においてあてはま る次元を挙げるよう求めた。その結果, 3 名が一致し て挙げた次元がこれらの 5 次元である。そのため, こ の 5 次元を日本のクラスにおける動機づけ構造の下位 次元としてひとまず仮定した。各次元の内容は, 以下 のとおりである。

(1)クラスにおける課題志向の動機づけ：学習および 課題への内発的価值を追求する傾向, (2)クラスに扔け る権威への動機づけ：教師からの承認を求める傾向, (3)クラスにおける承認への動機づけ：友だちからの承 認を求める傾向，(4)クラスにおける協調への動機づ け：クラスに調和していこうとする傾向，(5)クラスに おける参加への動機づけ：学業や行事に積極的にとり くもうとする傾向。

TARGET 構造の下位次元と本研究におけるクラス の動機づけ構造の 5 つの次元を比較すると, 課題およ び承認についてはどちらの構造においてもとり挙げら れている。また, TABLE 1 より, TARGET 構造にお いては権限の次元は生徒の自己決定と活動への参加の 2 つの内容を含んでいるが, クラス構造においては参 加の次元だけが独立してとりあげられている。さらに, TARGET 構造におけるグルーピング, 評価および時 間の次元がクラスの動機づけ構造ではとり挙げられず, 協調の次元が新たに採用されている。

つぎに，各々の次元の内容を反映すると思われる項 目を, 逆転項目を含む各次元 9 項目, 合計 45 項目作成 した。項目の作成にあたっては，クラスに対する生徒 の認知, 教師に対する生徒の認知, 友人に対する生徒 の認知, 課題に対する生徒の認知, 学習に対する生徒 自身の認知など，関連すると思われる内容をできるだ け広い範囲の場面にわたって反映させることを意図し て作成した。項目内容は, 権威・承認・協調・参加の 次元においてクラスについて非ねる項目が主であるが, 生徒個人についての項目も一部含まれている。課題志 向の次元については生徒個人についての項目が多く なっているが，これは TARGET 構造を定義した Epstein (1988), Maehr \& Midgley (1991), Ames (1992) ともに課題の次元を個人の内発的傾向と関連させてい 
るため，これらの定義に基づいて項目を作成したため である（TABLE 1, 2 参照)。

TABLE 2 因子分析結果

\begin{tabular}{|c|c|c|c|c|c|c|}
\hline 番号* & 項 & I & II & III & IV & $\mathrm{h}^{2}$ \\
\hline 30. & 勉強がよくできれば, 先生から認められることができます。 & .71 & .15 & -.08 & .16 & .56 \\
\hline 7. & テストでよい点をとれば，クラスのみんなから認められると思います。 & .67 & .07 & .03 & -.10 & .47 \\
\hline 22. & テストでよい点をとって, 先生から認めてもらいたいと思います。 & .67 & .21 & .15 & -.01 & .52 \\
\hline 18. & スポーツのできる人は, クラスのみんなから注目されます。 & .50 & .03 & .05 & .16 & .28 \\
\hline 26. & がんばれば先生から認められます。 & .50 & .32 & .18 & .37 & .53 \\
\hline 9. & クラブ活動をまじめにやれば, クラスのみんなが認めてくれると思います。 & .49 & .10 & .33 & -.04 & .36 \\
\hline 23. & クラスのみんなから期待されている人が学級委員に選ばれると思います。 & .40 & .06 & .17 & .08 & .20 \\
\hline 1. & 長所のある人は, 先生から認められます。 & .36 & .18 & .07 & .16 & .19 \\
\hline 4. & 勉強するのは, クラスのみんなから注目されたいからです。 & .36 & .19 & .11 & -.23 & .24 \\
\hline 5.5 & 先生は, まじめに勉強している人をほめます。 & .33 & .11 & .03 & .27 & .19 \\
\hline 3. & 自分から進んで勉強したいと思います。 & .21 & .68 & .09 & -.09 & .53 \\
\hline 10. & できるだけたくさんのことを勉強したいと思います。 & .19 & .68 & .17 & -.01 & .54 \\
\hline 19. & よくわからなかった問題は, わかるまで勉強しようと思います。 & .14 & .61 & .22 & .15 & .47 \\
\hline 13. & 勉強ができるようになることは, 楽しいです。 & .22 & .47 & .21 & .16 & .34 \\
\hline 14. $ђ$ & 授業中は, なるべく進んで発表したいと思います。 & .18 & .47 & .45 & .05 & .47 \\
\hline 17. & 勉強するのは，いままで自分の知らなかったことを知るためです。 & .16 & .44 & .26 & .15 & .32 \\
\hline 8. & クラブ活動に積極的に参加したいと思います。 & .20 & .07 & .60 & .00 & .41 \\
\hline 31. & クラス会や遠足には，積極的に参加したいと思います。 & .23 & .22 & .55 & .25 & .48 \\
\hline 11. & クラスの行事には, 自分からはあまり進んで参加したいとは思いません。（R）** & .00 & .18 & .45 & .04 & .24 \\
\hline 6. & クラスの決まりは, 必ず守りたいと思います。 & .23 & .27 & .44 & .21 & .37 \\
\hline 33. 今 & 実験や観察を自分で進んで行いたいと思います。 & -.01 & .35 & .39 & .17 & .31 \\
\hline 29. & 授業に自分から積極的に参加することはありません。（R） & -.05 & .24 & .33 & -.08 & .18 \\
\hline 16. & 勉強していてわからないところは, クラスの友だちに教えてもらいます。 & .16 & .20 & .32 & .30 & .26 \\
\hline 20. 7 & 友だちに親切にする人がクラスのみんなから認められると思います。 & .36 & .26 & .16 & .39 & .38 \\
\hline 27. & このクラスでうまくやっていくにはどうすればよいか, とても気になります。 & .13 & .15 & .12 & .38 & .20 \\
\hline 28. & 学級会では，なるべくみんなの意見に従います。 & .15 & .13 & .15 & .36 & .19 \\
\hline 2. & 勉強よりも友だちとの関係の方が気になります。 & .11 & -.02 & .10 & .29 & .11 \\
\hline 15. & テストで友だちよりもよい点をとる必要はないと思います。 & .09 & .07 & .05 & -.25 & .08 \\
\hline 24. & 無理してまで友だちから尊敬されたいとは思いません。（R） & .08 & -.01 & .12 & -.16 & .05 \\
\hline & 二 乗 和 & 3.24 & 2.70 & 2.14 & 1.27 & \\
\hline
\end{tabular}

* 項目番号は，原項目に対応している。

** $\mathrm{R}$ は逆転項目を示す。

これらの項目の内容的妥当性を判定するために，2 名の心理学専攻の大学院生が独立して, 項目が次元の 内容を表現しているかどうかを判定し，2名が一致し て選抜した項目だけを残した。さらに，質問項目の表 現および場面設定に関する適切さについて，調查を依 頼した中学校 $\mathrm{A}$ 校および $\mathrm{B}$ 校の各 1 名ずつ計 2 名の教 師が判定した。判定の基準は，(1)中学校 1 年生にとっ て表現は自然かどうか，(2)項目における場面設定は適 切かどうか, (3)使用されている漢字や表現が中学校 1
年生にとって困難を感じるものであるかどうかであっ た。その結果, 最終的に33項目がクラスの動機づけ構 造を測定する質問項目として使用された。

(2)個人の要因を測定する項目

クラスにおける達成目標と個人およびクラス要因の 関連を検討した渡辺 (1990) は, Ames \& Archer (1988) に基づき，達成目標と生徒の学習方法，課題遂行意欲, クラスへの適応, 原因帰属との関連を検討した。本研 究ではこれを参考に，個人の動機づけに関する認知的 
指標として原因帰属を採用した。その他に, 学業達成 に関連した認知的指標として, 生徒の能力認知に関す る測度を採用した。さらに，個人の適応感を表わす測 度として自尊尺度を採用した。

自尊 (self-esteem) 尺度：遠藤・安藤・冷川・井上 (1974) によって作成された自尊尺度23項目のうちから, 中学 校 1 年生にとって不自然でないと思われる項目 17 項目 を中学校 $\mathrm{A}$ 校および $\mathrm{B}$ 校 2 名の教師の意見を参考とし て選び，回答しやすいような形に一部変更して実施し た。自尊 (self-esteem) は社会的な適応の感情として定 義されており, 本尺度は生徒の適応感の指標として用 いられた。項目例は,「ほかの人が気になったり, 自分 がはずかしくなることがあります。」などであった。

能力認知に関する項目：Nicholls ら (1985) が使用し た能力認知項目を日本にあてはまるように一部修正し， 6 項目を作成した。英語, 数学, 国語, 理科, 社会お よび学習全般に関する自信について尋ねる内容であり, 教科に対する有能感の指標であると考えられる。項目 例は,「英語の勉強に, 自信があるほうだと思います。」 などであった。

原因帰属に関する項目：原因㷌属は, Ames \& Archer (1988) および渡辺 (1990)を参考に, 成功事態と 失敗事態についての典型的な帰属因として能力, 努力, 課題, 運の 4 㷌属因にどの程度帰属するかが測定され た。場面として, テストにおける成功場面と失敗場面 が選ばれた。測度は 8 項目から構成されている。

例としては, テストの成功場面における能力帰属項 目は,「テストでよい点数がとれたのは, じぶんの頭が よいからだと思うことがあります。」であった。また， テストの失敗場面における能力帰属項目は,「テストで よい点数がとれなかったのは, じぶんの頭がわるいか らだと思うことがあります。」であった。

(3)クラスの要因を測定する項目

クラスに関する認知的指標として, 渡辺 (1990) が使 用した生徒のクラスへの適応に関する測度を採用した。 また, クラスの動機づけ構造に関連する測度として, Maehr \& Fyans (1989) が作成したクラス文化測度を 採用した。さらに, クラスの雾囲気に関する測度とし て, 従来から教育社会心理学において研究されてきた クラスのモラールとの関連を検討するため, 根本 (1993) が作成したモラール測度をクラスに関する指標として 採用した。

クラスへの適応に関する項目：渡辺 (1990) が使用し たクラスへの適応測度を一部修正して使用した。内容 は, クラス全体への適応, 友だちへの適応, 教師への
適応の 3 項目から構成された。項目例は, 「自分がクラ スにうまくとけこんでいるほうだと思います。」な゙で あった。

クラス文化を測定する項目：Maehr \& Fyans (1989) は, 学校文化 (school culture) を測定する項目 (15 項目) を作成している。彼らによれば，学校文化の認知は生 徒の動機づけに影響を与える要因であり, ひいては達 成行動に関連すると仮定している。これは, 成就, 勢 力, 承認, 親和, 全体に対する知覚の下位次元から構 成されているが，クラスにもそのまま適用できると思 われるため, 表現をクラスに適するように一部修正し， 9 項目を作成した。項目例としては,「このクラスにい ると, 勉強が好きになります(成就)」,「このクラスでよ い成績をとることがとても大切です(勢力)」,「このクラ スの先生は, 生徒に期待しています(親和)」などであっ た。Maehr \& Fyans (1989) は, これらの項目が一因 子構造であり, 項目得点の合計を生徒の動機づけと達 成に影響を与える要因としているため, 本研究におい ても 9 項目の合計得点を算出し, クラス文化得点とし て使用した。

クラスのモラールに関する項目：クラスの動機づけ 構造はクラス全体の動機づけを問題としていることか ら，クラスのモラールと関連しているものと思われる。 そのため, クラスのモラールを測定するための項目と して, 根本 (1983) が作成したモラール測度を使用し た。根本によるモラール測度は依存性, 学級意識, 態 度, 関与, 自尊, 意欲, 二重性をとりあげているが, 本研究では, クラスの動機づけに関連すると思われる 依存性, 学級意識, 態度, 関与, 意欲を選定し, これ らに関する項目を使用した。自尊については個人要因 としてとり挙げており, また, 二重性についてはネガ ティブな要因であり, 動機づけ構造と関連を捉えにく かったため削除した。項目の選択については, 以下に 述べる項目内容について検討し, 中学校にもあてはま ると思われる内容の項目を 2 名の中学校教師が独立し て判定し， 2 名が一致して選抜した項目だけを使用し た。

根本によれば，依存性は教室内で他者に依存的であ る程度を表わし, 項目例としては「クラスで話し合い をしていて, なかなか決まらないときは, 先生がさっ さと決めてくれたほうがよいと思います。」などであ り，3 項目を使用した。学級意識は, 所属学級に対す る自我関与の程度を表わし,「自分のクラスの人が表彰 されたりすると，すごくうれしくなります。」な゙の項 目が含まれている。4 項目を選択して使用した。態度 
は, 学校や学級, 教師等に対する肯定的評価であり, 項目例として,「今の担任の先生に教わって，とてもよ かったと思います。」な゙があり，2 項目を選択して使 用した。関与は, 学級の活動に参加する程度を表わし ており，項目例は「クラスで何かするとき，夢中にな ることがあります。」などがあり，2 項目を使用した。 意欲は，学習に対する意欲を表わしており，項目例と して，「こクラスになってから，よく勉強するように なったと思います。」などがあり，4 項目を使用した。 手続：調查の実施は, 調査者および担任教師の立ちあ いのもとに，各クラスごとに集団で行われた。

クラスの動機づけ構造を測定する質問項目を実施す る際には, 調查者から以下のような教示が与えられた。 「あなたや, あなたのクラスについて,つぎのようなこ とはどれくらいあてはまりますか。あてはまるものを 質問項目の中から選んでください。」

回答形式はいずれの質問項目においても 4 件法を採 用しており，「とてもよくあてはまります」に 4 点,「す こしはあてはまります」に 3 点,「あまりあてはまりま せん」に 2 点,「まったくあてはまりません」に 1 点を それぞれ与えた。

\section{結果と考察}

\section{1.クラスの動機づけ構造を測定する質問項目の分析} 結果

(1)因子分析結果

評定の結果残つた 33 項目の各々について平均値を求 めた。本調査は 4 件法を採用しているために, 各項目 とも最低が 1 であり, 最高が 4 となる。平均が 3.5 以上 の項目は項目平均が高すぎると思われるので, これら の項目を削除したところ 4 項目が該当し，29項目が 残った。

つぎに，仮定したクラスの動機づけ構造を生徒がど のようにとらえているかを明らかにするために，この 29項目について因子分析を行った。初期解を主因子解 で求めたところ，第 5 因子以降は解釈が困難であった ため，4因子を抽出した。得られた因子に対してバリ マックス回転を行った。項目 2 (因子負荷量.29)を例外と して, 因子負荷量が.30に満たない項目を除外し，最終 的に項目を選定したところ，第 1 因子は 10 項目，第 2 因子は 6 項目，第 3 因子は 7 項目，第 4 因子は 4 項目 が得られ，計27項目が残った。項目内容および回転後 の因子構造が TABLE 2 に示されている。

各因子と，仮定したクラスの動機づけ構造の下位次 元との対応について検討すると，第 1 因子が権威への
動機づけおよび承認への動機づけと内容的に対応して いる。これらは，他者からの承認に対する動機づけと いう側面を持つので，承認への動機づけと再命名した。 第 2 因子が課題志向の動機づけと内容的に対応してい る。また，第 3 因子が参加への動機づけと内容的に対 応している。さらに，第 4 因子は協調への動機づけと 内容的に対応していることが明らかである。第 1 因子 について，生徒は教師からの承認も友だちからの承認 も同様に動機づけの要因として認識していることがわ かる。このように，3名の教師が挙げたクラスの動機 づけの下位次元と, 生徒の認知した動機づけの次元と はほほ一致していた。

(2)信頼性の検討

クラスの動機づけ構造を測定する下位次元項目の信 頼性に関して， $\alpha$ 係数による内部一貫性および 2 週間 後の再検査信頼性係数による安定性を求めた。TABLE 3 に各下位次元の $\alpha$ 係数および再検査信頼性係数を示 した。下位次元の信頼性について， $\alpha$ 係数による内部 一貫性を求めたところ, TABLE 3 より, 第 1 因子 が. 80 , 第 2 因子が. 81 , 第 3 因子が. 72 , 第 4 因子が. 56 であった。第 4 因子の $\alpha$ 係数が低いが，そのほかは満 足し得る内部一貫性が存在しているものと思われる。

TABLE 3 クラスの動機づけ構造の下位次元の信頼性係数

\begin{tabular}{lcc}
\hline \multicolumn{1}{c}{ 下位次元 } & $\alpha$ 係数 & $\begin{array}{c}\text { 再検査信頼性 } \\
\text { 係数 }(\mathrm{N}=53)\end{array}$ \\
\hline 承認への動機づけ & .80 & $.77^{* *}$ \\
課題志向への動機づけ & .81 & $.73^{* *}$ \\
参加への動機づけ & .72 & $.75^{* *}$ \\
協調への動機づけ & .56 & $.71^{* *}$ \\
\hline$* * \quad \mathrm{p}<.01$ & &
\end{tabular}

また， 2 週間後の再検査信頼性係数による安定性は, 第 1 因子が.77であり，第 2 因子が.73，第 3 因子が.75 であった。さらに第 4 因子が.71であった。これらの相 関係数はすべて $1 \%$ 水準で有意であった。必ずしも十 分に高いとはいえない相関係数であるが，ある程度の 安定性は認められたものと思われる。

\section{2.クラスの動機づけ構造と個人に関する諸要因との} 関連

本研究ではクラスの動機づけ構造に関する生徒の認 知を測定した。そのため, 生徒が認知したクラスの動 機づけ構造は, 生徒個人に関連する諸要因ともある程 度のかかわりを持つことが予想される。そこで, 生徒 が認知したクラスの動機づけ構造と, 個人の諸要因と 
の関連を明らかにすることを試みた。

個人の諸要因としてとり挙げたのは，個人の適応感 に関する指標として自尊感情，個人の達成に関する認 知的指標として能力認知，個人の動機づけの認知的指 標として原因帰属であり，原因帰属については成功事 態と失敗事態の典型的な帰属因として能力, 努力, 課 題, 運の 4 㷌属因を選び, 場面としてテストに扔ける 成功事態と失敗事態を設定した。各測度の信頼性につ いては, 自尊感情は $\alpha$ 係数が.88, 能力認知は $\alpha$ 係数 が.81であった。原因帰属については，1つ0項目ごと に検討しているので， $\alpha$ 係数は求めなかった。

因子分析の結果得られたクラスの動機づけ構造の下 位次元がこれらの個人の各要因にどの程度の貢献度で 影響を及ぼしているかを明らかにすることを目的とし て, クラスの動機づけ構造の 4 つの下位次元を説明変 数とし，個人の各要因を被説明変数として重回㷌分析 を行った。結果はTABLE 4 に示した通りである。ま ず，重相関係数（R）について検討すると，原因帰属 における失敗事態の運帰属について有意でなかったほ かは，すべての被説明変数について $1 \%$ 水準で有意で あった。重相関係数に関しては, 能力認知で.41, 自尊 感情で.33，原因㷌属の成功事態に抢ける努力㷌属 で.45の值が得られたほかはかなり低い値となってお り，クラスの動機づけ構造の次元が必ずしも個人に関 する各要因を高い割合で説明しているわけではないこ とがうかがえる。つぎに，標準偏回帰係数について検 討すると, 課題志向の次元が能力認知をかなりの貢献 度で説明している。能力認知は各教科に関する自信に ついて尋ねる内容であり，教科に対する有能感の指標 である。課題志向の次元は自律的で内発的な動機であ るため，教科に対する有能感の指標である能力の認知 と密接に関連しているものと思われる。すなわち，学 習に積極的にとり組むうちに良い結果を得ることで， さらに内発的な傾向が高められる過程である（速水， 1993）。また，協調の次元が自尊感情を説明している。 これは，協調の次元はクラスにおける周囲との親和性 と関連があり, 他方, 自尊感情は社会的な適応の感情 であり，生徒の適応感の指標として用いられたため, 協調の次元が自尊感情と関連していたものと思われる。 原因帰属については，まず成功事態において承認の次 元と能力帰属および努力帰属が関連している。それに 対して, 課題志向の次元が課題帰属と運帰属について 負の因果関係があった。また，参加の次元と努力帰属 抢よび課題帰属に関連があった。これらの結果は, 承 認の次元においては能力や努力など, 個人に属する資
質を認めるということであり，課題志向の次元では， 成功を課題や運などの個人の外的条件に帰属しないこ とを意味している。ところが，失敗事態においては， 承認の次元と課題帰属に関連があったが, 課題志向の 次元と能力㷌属, 課題帰属, 運㷌属の間に負の因果関 係が認められた。このように，内発的動機づけと関連 のある課題志向の次元では, 失敗を努力以外の要因に 㷌属させていないということが明らかとなった。

TABLE 4 個人の要因との重回帰分析結果（標準偏回㷌係数）

\begin{tabular}{|c|c|c|c|c|c|}
\hline \multirow{2}{*}{ 被説明変数 } & \multicolumn{2}{|r|}{ 明 } & \multicolumn{2}{|l|}{ 変 } & \multirow{2}{*}{$\mathrm{R}$} \\
\hline & 承 認 & 課題志向 & 加 & 協 & \\
\hline 能力認知 & .00 & $.37^{* *}$ & .06 & -.02 & $.41^{* *}$ \\
\hline 自尊感情 & .10 & -.01 & -.07 & $.31^{* *}$ & $.33^{* *}$ \\
\hline \multicolumn{6}{|l|}{ 原因帰属 } \\
\hline \multicolumn{6}{|l|}{ 成功事態) } \\
\hline 能力 & $.28^{* *}$ & -.03 & -.03 & -.09 & $.24^{* *}$ \\
\hline 努力 & $.23^{* *}$ & $.13^{+}$ & $.20^{* *}$ & -.02 & $.45^{* *}$ \\
\hline 課題 & .11 & $-.23^{* *}$ & $.20^{* *}$ & .04 & $.22^{* *}$ \\
\hline 運 & $-.12^{+}$ & $-.18^{*}$ & .11 & .04 & $.20^{*}$ \\
\hline \multicolumn{6}{|l|}{ 失敗事態) } \\
\hline 能力 & $.11^{+}$ & $-.25^{* *}$ & $.13^{+}$ & $.11^{+}$ & $.23^{* *}$ \\
\hline 努力 & .08 & .06 & .09 & .09 & $.25^{* *}$ \\
\hline 課題 & $.25^{* *}$ & $-.20^{* *}$ & .10 & -.04 & $.23^{* *}$ \\
\hline 運 & .08 & $-.16^{*}$ & .05 & -.06 & .14 \\
\hline
\end{tabular}

\section{3.クラスの動機づけ構造とクラスの諸要因との関連}

クラスの動機づけ構造とクラスの諸要因との間には 関連があることが予想される。本研究でとり挙げたク ラスのモラール，クラス文化の認知，クラスへの適応 の信頼性について， $\alpha$ 係数によって求めたところ，ク ラス文化の認知は.80, クラスへの適応は.72であった。 クラスのモラールの 5 つの下位次元の $\alpha$ 係数は, 学級 意識では.74, 態度では.83, 関与では.57, 意欲で は.72, 依存性では.45であった。関与の次元と依存性 の次元に㧍ける $\alpha$ 係数が低くなっているが，これは， 選択した項目数が 2 〜 項目と少ないことが影響して いるものと思われる。しかしながら, 妥当性について は，中学校においてあてはまると思われる内容の項目 を 2 名の中学校教師が独立して判定し, 2 名が一致し て選抜した項目だけを使用したことから，内容的には ある程度の整合性を持つと考え，これらの項目を使用 した。

クラスの動機づけ構造の下位次元がこれらのクラス 
の各要因にどの程度の貢献度で影響を及ほしているか を明らかにすることを目的として，クラスの動機づけ 構造の 4 つの下位次元を説明変数とし, クラスの各要 因を被説明変数として重回㷌分析を行った。結果は TABLE 5 に示した通りであるが，重相関係数（R）に ついて検討すると，すべての被説明変数について $1 \%$ 水準で有意であった。これらの重相関係数の結果は, 個人の諸要因との結果と比較すると, 全般的にかなり 高い数值を示している。とりわけ，クラス文化の認知 に対する重相関係数が.71であり,クラスのモラールの 意欲の次元では.69であるとおり,クラス文化の認知や クラスのモラールの意欲の次元においては, クラスの 動機づけ構造の 4 つの次元で, 被説明変数の分散の $50 \%$ 前後を説明している。このことは, クラスの動機 づけ構造を測定する質問項目が，クラスに関する諸要 因と密接に関連していることを示しているものと思わ れる。

TABLE 5 クラスの要因との重回帰分析結果（標準偏回㷌係数）

\begin{tabular}{|c|c|c|c|c|c|}
\hline \multirow{2}{*}{ 被説明変数 } & \multicolumn{2}{|c|}{ 説 } & \multicolumn{2}{|c|}{ 数 } & \multirow{2}{*}{$\mathrm{R}$} \\
\hline & 承 認 & 課題志向 & 参 & 協 & \\
\hline クラス文化 & $.49^{* *}$ & $.13^{*}$ & $.17^{* *}$ & $.09^{+}$ & $.71^{* *}$ \\
\hline クラスへの適応 & $.27^{* *}$ & $.13^{*}$ & $.27^{* *}$ & .06 & $.58^{* *}$ \\
\hline \multicolumn{6}{|c|}{ クラスのモラール } \\
\hline 意識 & $.22^{* *}$ & $.19^{* *}$ & $.23^{* *}$ & $.17^{* *}$ & $.62^{* *}$ \\
\hline 態度 & $.13^{+}$ & .00 & $.17^{*}$ & $.11^{+}$ & $.32 * *$ \\
\hline 関与 & .06 & .10 & $.34^{* *}$ & $.13^{*}$ & $.50^{* *}$ \\
\hline 意欲 & .08 & $.50^{* *}$ & $.22^{* *}$ & -.02 & $.69^{* *}$ \\
\hline 依存 & $.17^{* *}$ & $-.18^{*}$ & $-.23^{* *}$ & $.14^{*}$ & $.31^{* *}$ \\
\hline
\end{tabular}

$+.05<\mathrm{p}<.10 \quad * \mathrm{p}<.05 \quad * * \mathrm{p}<.01$

標準偏回帰係数について検討すると, 承認の次元が クラス文化の認知をかなりの貢献度で説明している。 また, 課題志向の次元および参加の次元もクラス文化 の認知を一定程度説明している。クラスへの適応につ いては, 承認の次元, 課題志向の次元, 参加の次元が 説明しているが，協調の次元との関連は認められな かった。協調の次元は, 他者志向的な動機であり, こ うした側面だけではクラスに適応していると認知する には至らないことを示していよう。つぎに，クラスの モラールに関する次元との関連であるが, 学級意識に 関して,クラスの動機づけ構造の 4 つの次元が説明し ていた。クラスのモラールの態度の次元については, クラスの動機づけ構造の参加の次元が説明していた。 また, クラスのモラールの関与の次元について, クラ
スの動機づけ構造の参加および協調の次元が説明して いる。クラスのモラールの関与の次元は, 前述したと おり生徒の学級の活動に参加する程度を表わすと定義 されている。クラスの動機づけ構造における参加の次 元がクラスのモラールの関与の次元を高い割合で説明 していたことは, クラスの動機づけ構造の参加の次元 の弁別力の高さを示しているものと思われる。ところ でクラスの動機づけ構造の協調の次元との関連は, つ ぎのように考えられるのではないだろうか。生徒たち は必ずしも自分から積極的に参加したい対象ではなく ても，友人を始めとする自分の周囲が参加するなら， 自分も一緒に参加してみようとしているのではないだ ろうか。すなわち，生徒は協調によって動機づけられ ている状態である。生徒を指導する立場からすれば, 教師にとっては協調の次元は生徒を動機づけるよい機 会である。速水 (1993) が指摘するとおり，内発的動機 づけと外発的動機づけが信条レベルにおいて密接につ ながっているとするならば，学業や行事に生徒をとり あえず参加させることができれば，そこからまた他の クラスの動機づけ構造に基づいて指導し, 学業や活動 に対する生徒の自発的興味を喚起する機会が得られる 可能性がある。教師が普段から協調の次元に基づいて 指導することにより, やる気のない生徒を活動に参加 させ，動機づけるきっかけを与える意味で，協調の次 元の重要性が見直される必要があろう。

さらに, クラスのモラールの意欲の次元を, クラス の動機づけ構造の課題志向の次元，参加の次元がかな りの貢献度で説明している。この結果は, クラスにお ける内発的動機づけの要因はクラスの動機づけ構造の 課題志向および参加と関係があることを示唆している。 クラスのモラールの依存の次元については, クラスの 動機づけ構造の承認の次元および協調の次元が説明し ており, 課題志向および参加の次元との間に負の因果 関係が認められた。これは,クラスの動機づけ構造の 承認および協調が社会的な志向であることを示唆して おり, 課題志向および参加が内発的・自主的な志向で あることをより強く裏づける結果を示していよう。ま た, 重回帰分析の結果は, 我国の学校教育の現場にお いて生徒を指導する立場からすると, クラスにおける 動機づけは個人の内発的な動機だけではなく, 承認や 協調のような社会的な動機も前述したように重要な役 割を果たすことを明確に示しているものと思われる。

\section{全体的考察}

これまで,クラスの動機づけをとりあつかった最近 
の研究には, クラスの動機づけを例えば習得的対競争 的 (Ames \& Archer, 1988) などのように，クラスの学習 に対するポジティブな側面とネガティブな側面の 2 つ の側面をとりあげて, それぞれの特徴を対比させる研 究が主流であった。しかし，教育実践においては，ク ラスのどのような側面が生徒の学習意欲を促進するの かについての情報がより必要とされているものと思わ れる。そのため, クラスにおける動機づけの要因を構 造的に捉え，その下位次元について検討を加える動き が最近さかんになってきている (Ames, 1992 ; Epstein, 1988)。これらの研究の特徵は, 従来までのクラス研究 と異なり, クラスの動機づけの側面について主として 着目し,さらに, クラス構造に基づき生徒を動機づけ る具体的な方略を開発している点に特色があるものと 思われる (Maehr \& Midgley, 1991)。本研究は, これらの 先行研究によって得られた知見を日本のクラス場面に 適用することの可能性を検討することを目的とした。

因子分析により, 生徒が認知した 4 つの因子の存在 が生徒の認知レベルから明らかとなり, クラスの動機 づけ構造は, 承認の次元, 課題志向の次元, 参加の次 元，協調の次元により測定された。また，クラスの動 機づけ構造の認知と個人の諸要因との間には関連が認 められた。さらに, クラスの動機づけ構造の各次元は, 関連するクラスの各要因を説明していた。とりわけ, クラスの動機づけ構造の各次元とクラス文化の認知, クラスへの適応, クラスのモラールのいくつかの次元 には強い関連が認められた。すなわち, クラスの動機 づけ構造は, クラスへの適応やクラス文化の認知, ク ラスのモラールなどクラスを特徴づける諸要因と密接 に関連しており, クラスの動機づけ構造において課題 志向の次元や参加の次元などのように生徒の内発的な 動機に関連する要因が動機づけの喚起にとって重要な だけでなく，承認の次元や協調の次元のような，社会 的・親和的な要因も重要であると生徒が認知している ことが明らかとなった。

Maehr \& Fyans（1989）は学校文化を測定する項目 を作成し，生徒個人の学習意欲および各教科の学業成 績との関連を検討している。彼らは，パス解析の結果 から学校文化の認知は生徒の動機づけに影響を与える 要因であり，ひいては達成行動に関連すると結論して いる。本研究では, 生徒の動機づけに影響を与えるの はクラスの動機づけの認知であると仮定し，さらにそ の下位次元と個人およびクラスの認知的諸指標との関 連を明らかにした点で, Maehr \& Fyansの結果をク ラスにおいても確認したものである。また, 生徒の動
機づけ構造と学級集団の社会的過程との関連について 検討した Schmuck (1978) は生徒の動機づけの要因とし て有態感 (competence) への動機, 勢力 (power) への動 機, 親和 (affiliation) への動機に分類している。このう ち，勢力への動機は，他者との関係の中で影響を持と うとする動機であり, 親和への動機は, 他者から影響 を望む動機であると仮定されている。これらの見解は, 本研究によって見いだされたクラスの動機づけ構造の 次元とは若干異なるが, クラス内における親和的な動 機の重要性をとり挙げた Schmuck の提案は, 本研究 におけるクラスの動機づけ構造の協調の次元の取り扱 いに重要な示唆を与えているものと思われる。

本研究で主に問題とした点は, 生徒が学習活動を喚 起されると感じているのはどのようなクラス構造であ るかについてである。結果は, 生徒の意欲を引きだす クラスの動機づけ構造は, 先行研究で得られた知見と 同様，鍵概念となり得るいくつかの下位次元に分類さ れることを示唆している。これらの知見を教育実践に 適応する場合, 教師は分類された下位次元に基づいて, 生徒の課題志向を高めることができるようなクラス環 境づくりや教材の設計に注意を払うことが重要であろ う。また，生徒がみんなを承認できるような環境づく りを普段から必がける必要がある。さらに，生徒が自 分から活動に参加し, 協調して物事にとり組めるよう にクラスを方向づけることによって, 生徒の学習や活 動への態度を変化させることが可能であるかもしれな い。その際, 教師が操作可能な要因を, 例えば TABLE 1 に示されている内容を参考として設定する必要があ ろう。TABLE 1 における Maehr \& Midgley（1991）の 方略は, 各次元が並列的に取り扱われているが, 今後 は本研究で得られたクラスの動機づけ構造の各次元が 行動の喚起・志向性・統制・強化といった動機づけの 諸機能とどのように対応しているかを検討しながら動 機づけ方略を設定することが重要であるものと思われ る。

本研究の知見を教育実践に活かすためには，本研究 で得られたクラスの動機づけ構造の下位次元をさらに 詳細に分析し，それらの次元に基づくクラス場面にお いて生徒を動機づけるための介入方略を設定し, 効果 を検討していくことが必要とされる。また，クラスに おいて非常に大きな要因は教師であるため, クラスや 教科担当の教師の様々な属性や指導法などの条件とク ラスの動機づけ構造の関連についての検討が望まれる。 これらの点を今後の課題としたい。 


\section{引用文献}

Ames, C. 1987 The enhancement of student motivation. In M.L. Maehr \& D.A. Kleiber (Eds.), Advances in motivation and achievement, Vol. 5 : Enhancing motivation. JAI Press.

Ames, C. 1992 Classroom : Goals, structures, and student motivation. Journal of Educational Psychology, 84, 261-271.

Ames, C., \& Archer, J. 1988 Achievement goals in the classroom : Students' learning strategies and motivation processes. Journal of Educational Psychology, 80, 260-267.

Brophy, J. 1983 Conceptualizing student motivation. Educational Psychologist, 18, 200-215.

遠藤辰雄・安藤延男・冷川昭子・井上祥治 1974 Self -esteem の研究 九州大学教育学部紀要, 18, 787 -797 .

Epstein, J.L. 1988 Effective schools or effective students : Dealing with diversity. In R. Haskins \& D. MacRae (Eds.), Policies for America's public schools : Teachers, equity, and indicators. Ablex.

浜名外喜男編 1988 教師が変われば子どもも変わる 北大路書房

長谷川俊明 1991 競争社会アメリカ一競争は善, 独 占は悪一 中公新書

速水敏彦 1993 外発的動機づけと内発的動機づけの 間 名古屋大学教育学部紀要一教育心理学科一, 40, 77-88.

喜多村和之編 1992 アメリカの教育 一「万人のた めの教育」の夢一 弘文堂

Maehr, M.L., \& Fyans, L.J.Jr. 1989 School culture, motivation and achievement. In M.L. Maehr \& C.Ames (Eds.), Advances in motivation and achievement, Vol. 6 : Motivation enhancing environments. JAI Press.

Maehr, M.L., \& Midgley, C. 1991 Enhancing student motivation : A school wide approach. Educational Psychologist, 26, 399-427.

Meece, J., Blumenfeld, P.C., \& Puro, P. 1989 A motivational analysis of elementary science learning environments. In $\mathrm{M}$. Matyas, $\mathrm{K}$. Tobin, \& B. Fraser (Eds.), Looking into windows : Qualitative research in science education. American Association for the Advancement of Science.

根本橘夫 1983 学級集団の構造と学級䨌囲気および モラールとの関係 教育心理学研究, 31, 26-34.

Nicholls, J.G. Patashnick, M., \& Nolen, S.B. 1985 Adolescents' theories of education. Journal of Educational Psychology, 77, 683-692.

Schmuck, R.A. 1978 Applications of social psychology to classroom life. In Bar-Tal, D., \& L Saxe (Eds.), Social psychology of education. Willey.

塩見邦雄 1994 子どもの学習意欲をたかめる一日本 とアメリカの教育の比較から一 北大路書房

Stipek, D.J. 1993 Motivation to learn; From theory to practice. Allyn \& Bacon.

田崎敏昭・狩野素朗 1990 学級集団理解の社会心理 学 ナカニシヤ出版

渡辺弥生 1990 クラスの学習目標の認知が生徒の学 業達成に及ほす影響について 教育心理学研究, 38, 198-204.

\section{謝辞}

本論文をまとめるにあたり，ご助言いただきました 筑波大学心理学系教授, 杉原一昭先生, 同助教授, 石 幔利紀先生に深く感謝いたします。

また，本研究を進めるにあたってご協力いただいた 筑波大学大学院教育研究科 (現在, 茨城県児童養護施設道心 園所属) 佐藤美奈子さん, 同大学大学院教育研究科, 天 貝由美子さんに深く感謝します。筑波大学大学院心理 学研究科 (現在, 茨城大学教育学部所属), 渡部玲二郎さん からは，本研究に対し貴重なご意見をいただきました。 同大学院心理学研究科, 今野裕之さんには, 統計処理 の点で,ご示唆をいただきました。ありがとうござい ました。

最後に, お世話になった中学校の先生方ならびに生 徒の皆様に厚くお礼を申し上げます。

(1994.5.30受稿, 11.16受理) 